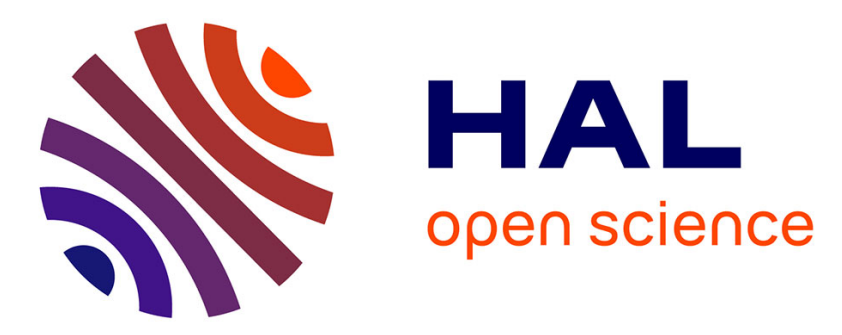

\title{
Environmental treasures: co-isolation of the first marine Chlamydiae and its protozoan host
}

Flávia Viana, Carmen Buchrieser

\section{To cite this version:}

Flávia Viana, Carmen Buchrieser. Environmental treasures: co-isolation of the first marine Chlamydiae and its protozoan host. Environmental Microbiology, 2016, 18 (8), pp.2295-2297. 10.1111/14622920.13264 . pasteur-01422511

HAL Id: pasteur-01422511

https://hal-pasteur.archives-ouvertes.fr/pasteur-01422511

Submitted on 7 Feb 2018

HAL is a multi-disciplinary open access archive for the deposit and dissemination of scientific research documents, whether they are published or not. The documents may come from teaching and research institutions in France or abroad, or from public or private research centers.
L'archive ouverte pluridisciplinaire HAL, est destinée au dépôt et à la diffusion de documents scientifiques de niveau recherche, publiés ou non, émanant des établissements d'enseignement et de recherche français ou étrangers, des laboratoires publics ou privés. 
4 5

6 7

8

9

10

11

12

13

14

15

16

17

18

19

20

21

22

23

24

25

26

27

28

29

30

31

32

33

34

35

36

37

38

39

40

41

42

43

.

\section{Environmental treasures: co-isolation of the first marine Chlamydiae and} its protozoan host 
Chlamydiae have always been an enthralling group of organisms. Back in 1907, when the first Chlamydia was discovered (now named Chlamydia trachomatis), they were described as borderline organisms and only much later recognized as a bacterial phylum (Moulder, 1966). All the presently known Chlamydiae are associated with eukaryotic hosts and are obligate intracellular bacteria that undergo a distinctive biphasic life cycle inside cytoplasmic membrane-bound vacuole inclusions (Abdelrahman and Belland, 2005; Kuo et al., 2015). The developmental cycle is characterized by the alternation between two physiologically and morphologically distinct forms, elementary bodies (EBs) and reticulate bodies (RBs). The bacteria are transmitted as inert but highly infectious EBs that, once inside the inclusions, differentiate to metabolically active RBs. The latter undertake several division cycles and transform back to EBs, capable of evading the host cell and infecting others. The cycle is not synchronized i.e., although a young inclusion will consist only of elementary bodies, mature inclusions will most of the time display the different forms (Kuo et al., 2015). Physical changes in the nucleoid structure and in the outer membrane allow the distinction between EBs and RBs but the trigger causing the switch remains a conundrum (Abdelrahman and Belland, 2005; Kuo et al., 2015). Until recently, EBs were believed to be metabolically inactive and their characteristically highly condensed chromatin was thought to cause a complete shutdown of transcription (Barry et al., 1993). However, this dogma has been challenged by recent findings that have shown that transcription and protein biosynthesis takes place in host-free EBs and that major metabolic routes are active in these particles (Haider et al., 2010; Sixt et al., 2013; Omsland et al., 2014).

For a long time, Chlamydiae were considered a small bacterial phylum composed of one single family, the Chlamydiaceae, which included diverse well-known human and animal pathogens such as the previously mentioned $C$. trachomatis, the causative agent of trachoma and of the worldwide most common sexually-transmitted disease (Everett et al., 1999). But in recent years researchers have shown that Chlamydiae are a much more diverse group of bacteria than previously thought as eight new families (Parachlamydiaceae, Waddliaceae, Simkaniaceae, Rhabdochlamydiaceae, Criblamydiaceae, Piscichlamydiaceae, Clavichlamydiaceae, Parilichlamydiaceae) have been added to the phylum Chlamydiae, radically changing our perception of these organisms (Horn, 2008; Taylor-Brown et al., 2015). Furthermore, these findings show 
that Chlamydiae are not only human or animal pathogens but that they encompass also diverse symbionts of a myriad of hosts such as protists, marine worms and arthropods. These newly discovered chlamydial families are often named "environmental chlamydia" given the range of habitats from where the isolates have been obtained from (Horn, 2008; Taylor-Brown et al., 2015). However, our current knowledge might be just the tip of the iceberg: a recent analysis of metagenomic and amplicon data suggested the existence of up to 181 putative Chlamydiae families comprising a large number of yet unidentified members and also of potential hosts and ecological niches (Lagkouvardos et al., 2014). The majority of the newly identified lineages derived from marine habitats, a commonly overlooked environment in the quest for new members of this phylum. Environmental Chlamydiae are more closely related to their pathogenic counterparts than to any other bacteria but, in contrast to what is observed for the Chlamydiaceae, the genomes of these environmental bacteria are diverse and display a large repertoire of genes likely associated with host-adaptation and ecology (Collingro et al., 2011; Domman and Horn, 2015). Interestingly, strains of environmental Chlamydiae have been shown to infect and thrive in human cells, suggesting a possible pathogenic role for some environmental chlamydia (Greub et al., 2003; Casson et al., 2006).

Chlamydiae have been the focus of several studies but the knowledge about this phylum remains limited, particularly for the environmental representatives. Their strict host-dependency has often hindered isolation and detection approaches, and the resulting impossibility to culture them in the laboratory hampered further studies on these bacteria. In this issue of EMI, Pizzetti and coworkers analyzed the chlamydial seasonal dynamics of the coastal lake Lago di Paola and used a new isolation approach that allowed the first co-isolation of a marine chlamydia (tentatively named Neptunochlamydia vexilliferae) with its natural host, an amoeba of the family Vexillifera. Remarkably, using a combination of a new high-throughput limited dilution approach that strongly limits the competition between protists (Schulz et al., 2015) and super resolution microscopy, the authors directly observed and identified chlamydia-host associations (Figure 1). Besides the successful isolation of $N$. vexilliferae and its host, this procedure lead also to a much more accurate quantification of the chlamydial diversity and dynamics in this environment compared to a previous report (Pizzetti et al., 2012). Curiously, this new isolate had not been detected in a polymerase chain reaction based study performed on Lago di Paola samples, perhaps because it does not belong to any of the major clusters of Chlamydiae previously identified in this lake (Pizzetti et al., 
110 2012). This method brings therefore not only significant advances for the isolation of new

111 Chlamydiae and other amoeba-associated bacteria, but also for future quantification studies as

112 it allows researchers to identify and study previously overlooked host-associated bacteria.

113 Bearing in mind the strict obligate intracellular lifestyle of Chlamydiae and their low

114 abundance in environmental samples compared to other free-living bacteria, analyzing

115 host-associated bacteria will be of major importance for future studies of these

116 organisms, particularly in previously unexploited environments and putative hosts. As

117 highlighted by this study, the seasonality of chlamydia matched the dynamics of host

118 abundance, showing once more the tight connection between the two partners. This work

119 brings also attention to the fact that the observed peak of amoeba abundance matched the time

120 of highest anthropogenic activity in the lake, which might have sanitary implications

121 considering the putative pathogenic potential of some environmental chlamydia.

122 Noteworthy also, is the fact that Pizzetti and coworkers succeeded to routinely maintain 123 the here identified environmental chlamydia species $N$. vexilliferae and its amoeba host in a 124 laboratory culture. Most of the known Chlamydiae families are represented by only a few 125 isolates and the lack of laboratory cultures poses a serious drawback for further studies. In 126 contrast, the fact that Pizzetti and coworkers managed to culture both partners in the lab 127 allows further studies and comparisons to be undertaken between chlamydia having different 128 lifestyles and hosts. Such research is of key importance for in depth understanding of how this 129 group of bacteria evolved, adapted to different hosts and surrounding environments, and 130 emerged as pathogens for animals and humans.

\section{Acknowledgements}

132 Research in CBs group is funded by the Institut Pasteur, ANR-10-LABX-62-IBEID and the 133 Fondation pour la Recherche Médicale grant $N^{\circ}$ DEQ20120323697. FV was supported by the 134 Infect-ERA project EUGENPATH (ANR-13-IFEC-0003-02). 
Abdelrahman, Y.M. and Belland, R.J. (2005) The chlamydial developmental cycle. FEMS Microbiol Rev 29: 949-959.

Barry, C.E., Brickman, T.J., and Hackstadt, T. (1993) Hc1-mediated effects on DNA structure: a potential regulator of chlamydial development. Molecular Microbiology 9: 273-283.

Casson, N., Medico, N., Bille, J., and Greub, G. (2006) Parachlamydia acanthamoebae enters and multiplies within pneumocytes and lung fibroblasts. Microbes Infect. 8: 1294-1300.

Collingro, A., Tischler, P., Weinmaier, T., Penz, T., Heinz, E., Brunham, R.C., et al. (2011) Unity in variety--the pan-genome of the Chlamydiae. Mol.Biol. Evol. 28: 3253-3270.

Domman, D. and Horn, M. (2015) Following the Footsteps of Chlamydial Gene Regulation. Mol. Biol. Evol. 32: 3035-3046.

Everett, K.D., Bush, R.M., and Andersen, A.A. (1999) Emended description of the order Chlamydiales, proposal of Parachlamydiaceae fam. nov. and Simkaniaceae fam. nov., each containing one monotypic genus, revised taxonomy of the family Chlamydiaceae, including a new genus and five new species, and standards for the identification of organisms. Int. J. Syst. Bacteriol. 49 Pt 2: 415-440.

Greub, G., Mege, J.L., and Raoult, D. (2003) Parachlamydia acanthamoeba enters and multiplies within human macrophages and induces their apoptosis. Infection and Immunity 71: 5979-5985.

Haider, S., Wagner, M., Schmid, M.C., Sixt, B.S., Christian, J.G., Häcker, G., et al. (2010) Raman microspectroscopy reveals long-term extracellular activity of Chlamydiae. Molecular Microbiology 77: 687-700.

Horn, M. (2008) Chlamydiae as symbionts in eukaryotes. Annu. Rev. Microbiol. 62: 113-131.

Kuo, C.-C., Stephens, R.S., Bavoil, P.M., and Kaltenboeck, B. (2015) Chlamydia. In, Bergey's Manual of Systematics of Archaea and Bacteria. Bergey's Manual of Systematics of Archaea and Bacteria, pp. 1-28.

Lagkouvardos, I., Weinmaier, T., Lauro, F.M., Cavicchioli, R., Rattei, T., and Horn, M. (2014) Integrating metagenomic and amplicon databases to resolve the phylogenetic and ecological diversity of the Chlamydiae. ISME J 8: 115-125.

Moulder, J.W. (1966) The relation of the psittacosis group (Chlamydiae) to bacteria and viruses. Аnпи. Rev. Microbiol. 20: 107-130.

Omsland, A., Sixt, B.S., Horn, M., and Hackstadt, T. (2014) Chlamydial metabolism revisited: interspecies metabolic variability and developmental stage-specific physiologic activities. FEMS Microbiol Rev 38: 779-801.

Pizzetti, I., Fazi, S., Fuchs, B.M., and Amann, R. (2012) High abundance of novel environmental chlamydiae in a Tyrrhenian coastal lake (Lago di Paola, Italy). Environ Microbiol Rep 4: 446452.

Pizzetti, I., Schulz, F., Tyml, T., Fuchs, B.M., Amann, R., Horn, M., and Fazi, S. (2016) Chlamydial seasonal dynamics and isolation of ' $\mathrm{C}$ andidatus Neptunochlamydia vexilliferae' from a Tyrrhenian coastal lake Environ Microbiol

Schulz, F., Tyml, T., Pizzetti, I., Dyková, I., Fazi, S., Kostka, M., and Horn, M. (2015) Marine amoebae with cytoplasmic and perinuclear symbionts deeply branching in the Gammaproteobacteria. Sci.Rep. 5: 13381.

Sixt, B.S., Siegl, A., Müller, C., Watzka, M., Wultsch, A., Tziotis, D., et al. (2013) Metabolic features of Protochlamydia amoebophila elementary bodies--a link between activity and infectivity in Chlamydiae. PLoS Pathog 9: e1003553.

Taylor-Brown, A., Vaughan, L., Greub, G., Timms, P., and Polkinghorne, A. (2015) Twenty years of research into Chlamydia-like organisms: a revolution in our understanding of the biology and pathogenicity of members of the phylum Chlamydiae. Pathog Dis 73: 1-15. 
187 Phylogenetic relationship of "Candidatus Neptunochlamydia vexilliferae" in the Chlamydiae 188 and super-resolution microscopy and fluorescence in situ hybridization images showing the 189 newly discovered bacterium (adapted from "Chlamydial seasonal dynamics and isolation of

190 'Candidatus Neptunochlamydia vexilliferae' from a Tyrrhenian coastal lake by Ilaria Pizzetti, 191 Frederik Schulz, Tomáš Tyml, Bernhard M. Fuchs, Rudolf Amann, Matthias Horn, Stefano 192 Fazi; DOI:10.1111/1462-2920.13111).

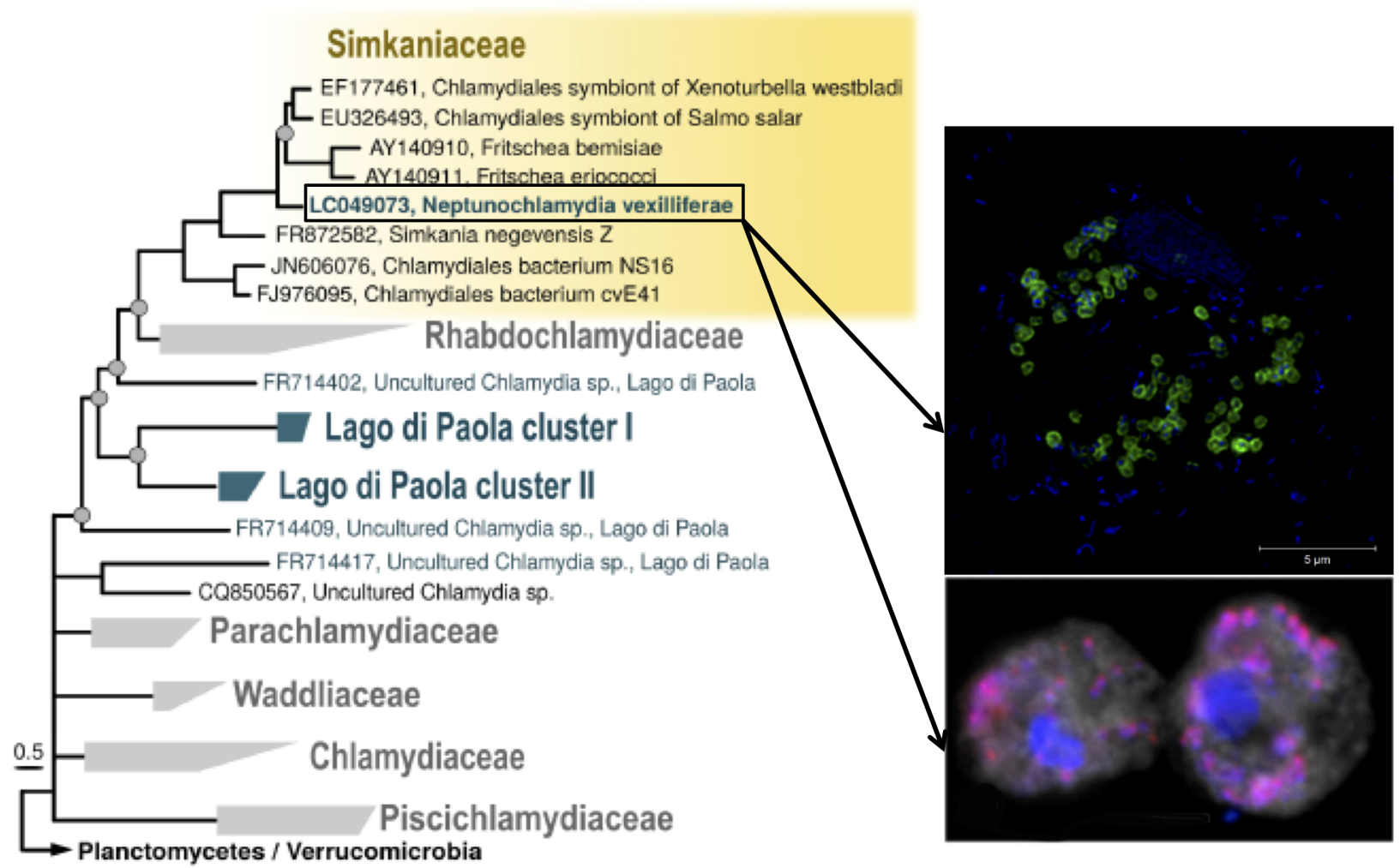

